\title{
MAP SHOWING BEDROCK TOPOGRAPHY AND SUBCROP OF SELECTED BEDS BENEATH ALLUVIAL DEPOSITS OF PARTS OF THE NEWBURGH AND YANKEETOWN QUADRANGLES, HENDERSON AND DAVIESS COUNTIES, KENTUCKY \\ By
}

Ronald L. Norris

\section{MISCELLANEOUS GEOLOGIC INVESTIGATIONS MAP I-803}

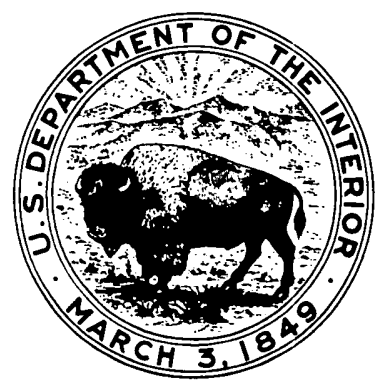

